\title{
PENGARUH METODE BELAJAR DAN RASA PERCAYA DIRI TERHADAP HASIL BELAJAR MATEMATIKA SISWA
}

\author{
Hasbullah \\ Program Studi Pendidikan Matematika, Universitas Indraprasta PGRI Jakarta \\ Jl. Nangka No.58C Tanjung Barat Jagakarsa Jakarta, hasbule@gmail.com
}

\begin{abstract}
ABSTRAK
Tujuan penelitian ini adalah untuk mengetahui pengaruh metode belajar terhadap hasil belajar matematika siswa, Untuk mengetahui pengaruh Rasa percaya diri siswa terhadap hasil belajar matematika siswa, dan Untuk mengetahui pengaruh interaksi metode belajar dengan rasa percaya diri terhadap hasil belajar matematika.

Metode penelitian yang digunakan adalah metode exsperimen. Sampel diambil sebanyak 30 orang siswa dengan 15 siswa kelas kontrol dan 15 siswa kelas exsperimen, dan teknik pengambilan sampel dilakukan secara acak sederhana. Pengumpulan data dilakukan dengan penyebaran angket langsung kepada sampel. Analisis data menggunakan statistika deskriptif seperti mencari mean, median, modus, standar deviasi, dan statistika inferensial.

Hasil penelitian menunjukkan: 1) Ada pengaruh metode belajar terhadap hasil belajar matematika siswa $F_{\text {hitung }}(39,107)>F_{\text {tabel }}(4,02)$. 2) Ada pengaruh rasa percaya diri siswa terhadap hasil belajar matematika siswa dengan $\left.F_{\text {hitung }}(9,282)>t_{\text {tabel }}(4,02) .3\right)$. Ada interaksi metode belajar dengan rasa percaya diri siswa dengan dengan $\mathrm{F}_{\text {hitung }}(7,431)>\mathrm{F}_{\text {tabel }}(4,02)$.
\end{abstract}

Kata kunci : Metode belajar, Contextual Teaching Learning, Rasa percaya diri dan Hasil belajar matematika

\begin{abstract}
The purpose of this study was to determine the effect of learning method on students' mathematics learning outcomes, to determine the effect of self-confidence of students to mathematics student learning outcomes, and to determine the effect of the interaction with the learning method confidence in mathematics learning outcomes.

The method used is the method exsperimen. Samples were taken by 30 students to 15 students in the control class and 15 students of class exsperimen, and the sampling technique is simple random. The data was collected by distributing questionnaires directly to the sample. Data analysis using descriptive statistics such as finding the mean, median, mode, standard deviation, and inferential statistics.

The results showed: 1) There is a method of studying the effect on students' mathematics learning outcomes Fcount (39.107)> F table (4.02). 2) There is the influence of students' confidence in mathematics learning outcomes of students with Fcount (9.282)> TTable (4.02). 3). There is a learning method of interaction with the confidence of students with the Fcount (7.431)> F table (4.02).
\end{abstract}

Keywords : learning method, Contextual Teaching Learning, confidence and Mathematics learning outcomes

\section{Pendahuluan}

$\begin{array}{ll}\text { Mengingat objek matematika } & \text { konkret sehingga konsep matematika } \\ \text { abstrak, maka dalam pembelajaran } & \text { dapat dipahami betul oleh peserta didik, } \\ \text { matematika dimulai dari objek yang } & \text { apalagi jika dikaitkan dengan }\end{array}$


kemampuan peserta didik untuk menggunakan daya nalarnya dalam memecahkan masalah yang ada. Untuk itulah, Depdiknas (2002:6) menyatakan bahawa "Materi matematika dan penalaran matematika merupakan dua hal yang tidak dapat dipisahkan, yaitu materi matematika dipahamai melalui penalaran dan penalaran dilatih melalui belajar materi matematika.”

Sudjana mengemukakan, "Hasil belajar adalah kemampuan-kemampuan yang dimiliki siswa setelah menerima pengalaman belajarnya" (Nana Sudjana, 2004: 22). Selanjutnya Nasution juga berpendapat : "Hasil Belajar sebagai suatu perubahan yang terjadi pada individu yang belajar bukan saja perubahan mengenai pengetahuan tetapi juga dalam bentuk kecakapan, kebiasaan, sikap, pengertian, penguasaan dan penghargaan dalam diri pribadi individu yang belajar"(S. Nasution, 1992: 39). "Hasil belajar adalah perubahanperubahan dalam pengetahuan, pemahaman keterampilan dan nilai sikap yang bersifat konstan/menetap" (Winkel, 1996: 15).

Dari beberapa pendapat di atas jelaslah bahwa seseorang yang sudah belajar tidak sama keadaannya dengan saat ketika belum belajar. Perubahan tingkah laku yang didapat setelah proses belajar, menurut Benjamin Bloom seperti yang dikutip oleh Sudjana, dapat diamati melalui tiga ranah yaitu :

1. Ranah kognitif: berkenaan dengan hasil belajar intelektual yang terdiri dari enam aspek yaitu pengetahuan atau ingatan, pemahaman, aplikasi, analisis, sisntesis, dan evaluasi.

2. Ranah Afektif: berkenaan dengan hasil belajar sikap yang terdiri dari lima aspek yaitu penerimaan, jawaban atau reaksi, penilaian, organisasi dan internalisasi.

3. Ranah Psikimotorik : berkenaan dengan hasil belajar keterampilan dan kemampuan bertindak.

Ketiga ranah tersebut menjadi objek penilaian hasil belajar. Diantara ketiga ranah itu, ranah kognitiflah yang paling banyak dinilai oleh para dosen di kampus karena berkaitan dengan kemampuan para mahasiswa dalam menguasai isi bahan pengajaran. (Sudjana, 2004: 22-23)

Senada dengan pendapat di atas, Russefendi mengemukakan "Kegiatan belajar mencakup tiga aspek, yaitu kognitif, afektif dan psikomotor. Aspek kognitif berhubungan dengan intelektualitas dan ilmu pengetahuan, dan aspek afektif berhubungan dengan sikap dan minat." (Ruseffendi, 1990: 122).

Hasil belajar yang diperoleh biasanya berbeda antara siswa yang satu 
dengan yang lainnya. Perbedaan ini disebabkan oleh berbagai faktor, antara lain faktor kematangan, latar belakang pribadi masing-masing, sikap dan bakat terhadap suatu bidang pelajaran, jenis mata pelajaran, dan sebagainya. Hasil belajar di dalam kelas dapat diterapkan kedalam situasi-situasi di luar kelas. Dengan kata lain, siswa dapat dikatakan berhasil belajar bila ia dapat mentransfer hasil belajarnya kedalam situasi-situasi yang sesungguhnya.

Belajar merupakan proses yang unik dimana banyak faktor yang mempengaruhi keberhasilan belajar. Secara garis besar ada 2 faktor yang mempengaruhi hasil belajar, yaitu:

1. Faktor intern, yakni faktor yang ada pada diri siswa itu sendiri yang disebut faktor individual. Menurut Slameto faktor ini dibedakan menjadi tiga faktor, yaitu : "(1) faktor jasmaniah, (2) faktor psikologis dan (3) faktor kelelahan"(Slameto, 1991: 56)

2. Faktor ekstern, yakni faktor yang ada diluar siswa atau faktor sosial. Slameto menjabarkan lagi faktor ini menjadi tiga faktor utama, yaitu "faktor keluarga, kampus, dan masyarakat"(Slameto, 1991: 62).

Memperhatikan faktor-faktor tersebut diatas, ternyata keberhasilan belajar siswa selain ditentukan oleh faktor-faktor yang ada pada diri siswa sendiri juga dipengaruhi oleh lingkungannya. Kedua faktor ini mempunyai peranan yang sangat besar dalam menentukan keberhasilan belajar mahasiswa. Oleh karena itu, siswa yang memperoleh hasil belajar kurang memuaskan belum bisa disimpulkan kalau anak tersebut bodoh, sebab masih banyak faktor yang turut menentukan keberhasilan belajarnya.

Berdasarkan uraian dan beberapa pendapat/teori di atas, maka dapat disimpulkan bahwa yang dimaksud hasil belajar matematik adalah pola-pola perubahan tingkah laku seseorang yang meliputi asfek kognitif, afektif dan/atau psikomotor setelah menempuh kegiatan belajar matematika yang tingkat kualitas perubahannya sangat ditentkan oleh faktor-faktor yang ada dalam diri siswa dan lingkungan sosial yang mempengaruhinya.

Strategi yang belakangan ini dianut tentang belajar antara lain siswa mengkontruksikan sendiri pemahamannya. Pembelajaran kontekstual membantu guru mengaitkan antara materi yang diajarkan dengan situasi dunia nyata siswa dan mendorong siswa membuat hubungan antara pengetahuan yang dimilikinya dengan penerapannya dalam kehidupan mereka sehari-hari, dengan melibatkan tujuh 
komponen utama pembelajaran efektiif antara lain: contructivism, questioning, inquiry, learning community, modeling, reflection dan authentic assessment (Rohman, 2003: 14). Tujuh prinsip dalam pembelajaran kontekstual tersebut antara lain:

\section{a. Kontruktivisme (contructivism)}

Kontruktivisme merupakan landasan berpikir (filosofi) pendekatan CTL, yaitu bahwa pengetahuan dibangun oleh manusia sedikit demi sedikit, yang hasilnya diperluas melalui konteks yang terbatas dan tiba-tiba. Pengetahuan bukanlah seperangkat fakta-fakta, subkonsep atau kaidah yang siap untuk diambil dan diingat. Manusia harus mengkontruksi pengetahuan itu dan memberi makna melalui pengalaman nyata. Pengetahuan bukanlah sesuatu yang tergantung dari yang memiliki pengetahuan. Siswa dapat menciptakan atau mengkontruksi pengetahuannya sendiri dengan mencoba memahaminya melalui pengalamannya. Segala sesuatu yang kita tahu, kita telah mengkontruksinya sendiri (Heruman, $2003: 15)$.

\section{b. Menemukan (Inquiry)}

Suatu kegiatan inti dari pembelajaran berbasis CTL.
Pengetahuan dan ketrampilan yang diperoleh siswa diharapkan bukan hasil mengingat seperangkat faktafakta, tetapi hasil dari menemukan sendiri. Guru harus selalu merancang kegiatan yang merujuk pada kegiatan menemukan, apapun materi yang diiajarkan. Inquiry mengandung aspek observasi, bertanyya, berhipotesis, pengumpulan data dan kesimpulan.

\section{c. Bertanya (Questioning)}

Pengetahuan yang dimiliki seseorang selalu bermula dari bertanya. Pertanyaan merupakan stimulus yang mendorong anak untuk berpikir dan belajar. Bertanya memegang peranan penting, sebab pertanyan dapat memotivasi peran serta siswa dalam belajar, seperti yang dikemukakan oleh Hasibuan \& Mudjiono (dalam Eryanti, 2002 : 6) sebagai berikut : Bertanya memegang peranan penting sehingga pertanyaan dapat membangkitkan minat dan rasa ingin tahu siswa terhadap masalah yang sedang dibicarakann, dapat meningkatkan pola piker dan belajar secara efektif, serta berpikir itu sendiri adalah bertanya. Menurut Tobing ( dalam Eryanti, 2002 : 7) kemampuan mengajukan pertanyaan dapat 
meningkatkan kualitas dan kuantitas hasil proses belajar mengajar.

\section{d. Masyarakat belajar (Learning Community)}

\section{Learning}

menyarankan agar hasil pembelajaran diperoleh dari hasil kerja sama dengan orang lain. Dalam kelas CTL, guru disarankan selalu melaksanakan pembelajaran dalam kelompok belajar. Siswa dibagi dalam kelompok-kelompok yang anggotanya heterogen, sehingga masing-masing anggota kelompok bisa saling berinteraksi dalam belajar, misalnnya siswa yang satu bisa bertanya pada yang lain dan yang lain bisa menjelaskannya. Dengan demikian dalam pembelajaran ini perlu ada komunikasi dua arah.

\section{e. Pemodelan (Modelling)}

Pemodelan dalam CTL adalah sebuah pembelajaran keterampilan atau pengetahuan tertentu perlu ada model yang bisa ditiru. Model itu bisa berupa cara mengoperasikan sesuatu, misalnya guru memberikan contoh mengajarkan sesuatu dengan membawa wujud nyata, jadi dalam pemodelan, ada yang bisa ditiru dan diamati oleh siswa. Di samping itu cara guru mendemonstrasikan dalam membuktikan suatu teorema dapat juga disebut pemodelan. Namun demikian pemodelan dalam matematika pada dasarnya hanyalah mengarahkan dan membimbing langkah siswa dalam bekerja dan bukan sebagai tujuan akhir. Dalam pembelajaran kontekstual, guru bukan satu-satunya model, teman sekelompok atau teman sekelas dapat pula dijadikan model. Di samping itu pemmbelajaran kontekstual memberikan kesempatan untuk meniru dari luar sekolah jika hal itu diperlukan.

\section{f. Refleksi (Reflection)}

Refleksi adalah cara berpikir tentang apa yang baru dipelajari atau berpikir kebelakang tentang apa-apa yang sudah dilakukan di masa yang lalu. Refleksi merupakan respon terhadap kejadian, aktifitas, atau pengetahuan yang baru diterima. Guru diharapkan dapat mengaitkan materi yang dipelajari dengan kehidupan nyata dan mengaitkan pengetahuan yang dimiliki siswa dengan pengetahuann yang baru. Dengan demikian siswa merasa telah memperoleh sesuatu yang berguna bagi dirinya tentang apa yang baru dipelajarinya. Realisasi refleksi dalam pembelajaran, diakhir pembelajaran guru menyisakan 
waktu sejenak untuk meminta siswa menyatakan, menuliskan, atau membuat pernyataan langsung tentang apa-apa yang diperolehnya hari itu, catatan atau journal di buku siswa, diskusi, hasil karya,atau kesan dan saran siswa mengenai pembelajaran hari itu.

g. Penilaian yang sebenarnya (Authentic Assessment)

Penilaian autentik adalah suatu istilah yang diciptakan untuk menjelaskan berbagai metode penilaian alternative. Penilaian autentik merupakan penilaian yang dapat mengukur penerapan pengetahuan di dalam berbagai konteks autentik., sehingga yang diukur adalah suatu kemampuan yang benar-benar merupakann kemampuan sehari-hari yang dimiliki siswa. Berbeda dengan penilaian alternative penilaian siswa dilakukan sebaliknya bukan kemampuan sehari-hari siswa, misalnya penilaian terhadap hasil karya yang dibuat dengan pemberian waktu yang khusus dan lama, sehingga berbeda dengan hasil kesehariannya. Penilaian autentik bertujuan untuk menyediakan informasi yang benar dan akurat mengenai apa yang benarbenar diketahui dan dapat dilakukan oleh siswa, atau tentang kualitas program pendidikan. (Rahman, 2003 : 14) Authentic Assessment adalah proses pengumpulan berbagai data atau informasi yang autentik, yang bias memberikan gambaran perkembangan siswa. Data yang dikumpulkan dari authentic assessment harus diperoleh dari kegiatan nyata yang dikerjakan siswa pada saat melakukan proses pembelajaran. Penilaian autentik menghendaki menilai kemampuan siswa dengan berbagai cara, tidak hanya dari ulangan tulis. Penilaian bias terhadap proses kegiatan dan laporannya, pekerjaan rumah, kuis, karya siswa, presentasi atau penampilan siswa, demonstrasi, jurnal, hasil pengamatan, hasil tes tertulis, dan karya tulis (Rahman, $2003: 15)$.

Pembelajaran kontekstual (CTL) dapat dijalankan tanpa harus mengubah kurikulum dan tatanan yang ada. Oleh karena itu pembelajaran ini bisa diterapkan pada sekolah dasar dan menengah khususnya Madrasah Tsanawiah (MTs). Dalam kelas kontekstual, tugas guru adalah membantu siswa mencapai tujuan, dalam hal ini guru lebih banyak berurusan dengan strategi dari pada pemberian informasi, tugas guru mengelola kelas sebagai sebuah team yang bekerja sama untuk 
menentukan sesuatu yang baru datang dari menemukan sendiri, bukan dari apa yang dikatakan guru semata, begitu peran guru di kelas yang dikelola dengan pendekatan kontekstual (Rahman, 2003 : 1). Menurut Wilson (2001 : 23) pembelajaran kontekstual adalah suatu konsep bagi pembelajarann yang menolong guru dalam menghubungkan topic yang diajarkan dengan situasi dunia nyata, sedangkan bagi siswa sebagai motivasi untuk membuat pengaitan antara pengetahuan dengan kehidupannya baik pada keluarga, masyarakat dan aktivitas lainnya. Menurut Departemen Pendidikan Nasional (2002 : 7) pembelajaran kontekstual dapat dikatakan sebagai sebuah pendekatan pembelajaran yang mengakui dan menunjukkan kondisi alamiah dari pengetahuan. Pembelajaran kontekstual bukanllah jenis pendekatan baru. Filosofi yang menndasari pendekatan kontekstual sudah lama dikembangkan.

Melalui landasan filosofis konstruksi, CTL) dipromosikan menjadi alternatif strategi belajar yang baru. Konstruktivisme sebagai pendekatan pembelajaran yang saat ini menjadi paradigma baru dalam pendidikan, sebenarnya merupakan pandangan dalam filsafat yang dikemukakan oleh Giombatista Vico (dalam Rustandi, 2002 : 9) yang berpandangan bahwa pengetahuan adalah hasil konstruksi manusia, melalui interaksi dengan objek, penomena, pengalamann, dan lingkungan mereka. Selanjutnya konstruktivisme dikembangkan oleh Piaget. Menurut Piaget (dalam Dahar, 1996 : 12) Konstruktivisme adalah sustu pandangan bahwa pengetahuan itu dibangun di dalam pikiran siswa. Pengetahuan itu tidak dapat ditransfer langsung oleh guru ke dalam pikiran siswa, melainkan melalui proses perubahan yang memerlukan konstruksi aktif siswa, selain itu pembelajaran dalam konstruktivisme tersebut dapat dikatakan bahwa konstruktivisme menekankan tentang sifat dasar bagaimana manusia belajar dan guru konstruktivis tidak hanya semata-mata memberikan pengetahuan kepada siswa, tetapi siswa sendiri yang harus membangun pengetahuan di dalam benaknya. Berdasarkan pemikiran konstruktivisme tersebut, CTL lahir dan berkembang menjadi suatu strategi baru dalam belajar

Orang yang dikatakan memiliki kepercayaan diri ialah orang yang merasa puas dengan dirinya (Gael Lindenfield dalam Kamil, 1998: 3). Adapun gambaran merasa puas terhadap dirinya adalah orang yang merasa mengetahui dan mengakui terhadap ketrampilan dan kemampuan yang dimilikinya, serta mampu menunjukkan keberhasilan yang 
dicapai dalam kehidupan bersosial. Untuk mencari atau menggali definisi yang akurat tentang percaya diri, maka harus menganalisis tentang unsur-unsurnya yang khas. Hal ini dilakukan dengan mendaftarkan sifatsifat dan ketrampilanketrampilan hasil pengamatan terhadap orang yang memiliki tingkat kepercayaan diri yang tinggi.

Menurut Angelis (2000: 10) kepercayaan diri merupakan suatu keyakinan dalam jiwa manusia bahwa tantangan hidup apapun harus dihadapi dengan berbuat sesuatu. Kepercayaan diri itu lahir dari kesadaran bahwa jika memutuskan untuk melakukan sesuatu, sesuatu itu pula yang harus dilakukan. Kepercayaan diri itu akan datang dari kesadaran seorang individu bahwa individu tersebut memiliki tekad untuk melakukan apapun, sampai tujuan yang ia inginkan tercapai.

Menurut Hakim (2005: 6), rasa percaya diri yaitu suatu keyakinan seseorang terhadap segala aspek kelebihan yang dimilikinya dan keyakinan tersebut membuatnya merasa mampu untuk bisa mencapai berbagai tujuan di dalam hidupnya. Jadi, dapat dikatakan bahwa seseorang yang memiliki kepercayaan diri akan optimis di dalam melakukan semua aktivitasnya, dan mempunyai tujuan yang realistik, artinya individu tersebut akan membuat tujuan hidup yang mampu untuk dilakukan, sehingga apa yang direncanakan akan dilakukan dengan keyakinan akan berhasil atau akan mencapai tujuan yang telah ditetapkannya.

Menurut Hakim (2005: 5-6) ciriciri orang yang percaya diri antara lain :

1. Selalu bersikap tenang di dalam mengerjakan segala sesuatu;

2. Mempunyai potensi dan kemampuan yang memadai;

3. Mampu menetralisasi ketegangan yang muncul di dalam berbagai situasi;

4. Mampu menyesuaikan diri dan berkomunikasi di berbagai situasi;

5. Memiliki kondisi mental dan fisik yang cukup menunjang penampilannya;

6. Memiliki kecerdasan yang cukup;

7. Memiliki tingkat pendidikan formal yang cukup;

8. Memiliki keahlian atau keterampilan lain yang menunjang kehidupannya, misalnya ketrampilan berbahasa asing;

9. Memiliki kemampuan bersosialisasi;

10. Memiliki latar belakang pendidikan keluarga yang baik;

11. Memiliki pengalaman hidup yang menempa mentalnya menjadi kuat dan tahan di dalam menghadapi berbagai cobaan hidup; 
12. Selalu bereaksi positif di dalam menghadapi berbagai masalah, misalnya dengan tetap tegar, sabar, dan tabah dalam menghadapi persoalan hidup.

Menurut Hakim (2005: 8-9) ciriciri orang yang tidak percaya diri antara lain :

1. Mudah cemas dalam menghadapi persoalan dengan tingkat kesulitan tertentu;

2. Memiliki kelemahan atau kekurangan dari segi mental, fisik, sosial, atau ekonomi;

3. Sulit menetralisasi timbulnya ketegangan di dalam suatu situasi;

4. Gugup dan kadang-kadang bicara gagap;

5. Memiliki latar belakang pendidikan keluarga kurang baik;

6. Memiliki perkembangan yang kurang baik sejak masa kecil;

7. Kurang memiliki kelebihan pada bidang tertentu dan tidak tahu bagaimana cara mengembangkan diri untuk memiliki kelebihan tertentu;

8. Sering menyendiri dari kelompok yang dianggapnya lebih dari dirinya;

9. Mudah putus asa;

10. Cenderung tergantung pada orang lain dalam mengatasi masalah;

11. Pernah mengalami trauma;

12. Sering bereaksi negatif dalam menghadapi masalah, misalnya dengan menghindari tanggung jawab atau mengisolasi diri, yang menyebabkan rasa tidak percaya dirinya semakin buruk.

Berdasarkan beberapa pengertian tersebut maka dapat ditarik kesimpulan bahwa rasa percaya diri adalah kesadaran individu akan kekuatan dan kemampuan yang dimilikinya, meyakini adanya rasa percaya dalam dirinya, merasa puas terhadap dirinya baik yang bersifat batiniah maupun jasmaniah, dapat bertindak sesuai dengan kapasitasnya serta mampu mengendalikannya.

\section{Metode Penelitian}

Tujuan penelitian, untuk memperoleh model pembelajaran yang paling efektif dalam memperbaiki kreativitas berpikir siswa, maka metode penelitian yang digunakan adalah metode eksperimen.

Donald Ary (1997 : 404 ) dalam sebuah buku "Pengantar Penelitian Dalam Pendidikan, Surabaya, Usaha Nasional. Mengatakan bahwa metode eksperimen dilakukan untuk menguji interaksi antara variable penelitian dengan disain faktoral. Dalam penelitian ini dSiain yang dipilih disesuaikan dengan hipotesis yang akan diuji, salah satu hipotesis yang akan diuji adalah mengidentifikasikan apakah terdapat interaksi antara metode belajar dan rasa 
percaya diri terhadap hasil belajar matematika siswa.

Hal ini didasarkan atas asumsi bahwa apabila hipotesis yang akan diuji adalah hipotesis interaksi maka pengujian hipotesis tersebut hanya dapat dilakukan dengan menggunakan disain factor ( Donald Ary, 1977 : 338 ). Mengacu pada banyaknya variable dan sub variable yang ada dalam penelitian, maka digunakan disain factor $2 \times 2$, variable-variabel tersebut diantaranya adalah :

1. Variabel Bebas, yaitu :
a. Metode Pembelajaran ( A )
b. Rasa Percaya Diri ( B )

2. Variabel terikat, yaitu Hasil Belajar pada matematika.

Dalam hal ini variable terikat adalah hasil belajar matematika siswa kelas XI SMKN 1 Rangkasbitung. Sedangkan Variabel bebasnya adalah metode pembelajaran yang digunakan guru dalam menyampaikan materi pelajaran pada siswa.

Tabel 1. Skema disain faktoral $2 \times 2$

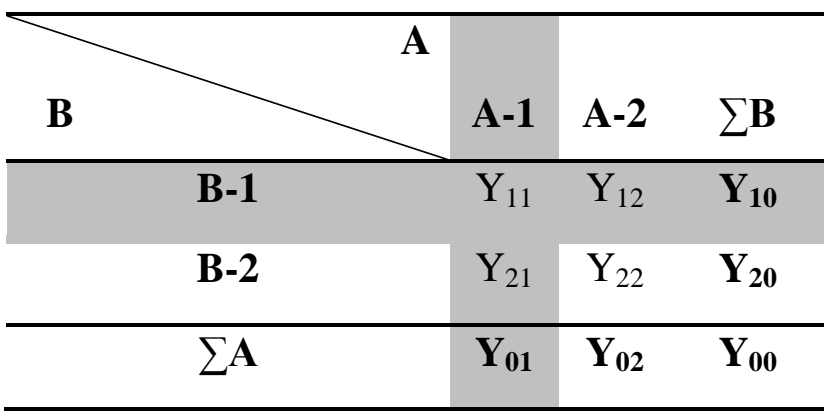

Keterangan :

A : Metode Pembelajaran
A1 : Metode Konvensional

A2 : Metode Kontekstual

B : Rasa Percaya Diri

B1 : Rasa Percaya Diri Tinggi

B2 : Rasa Percaya Diri Sedang

Y : Hasil Tes Belajar Siswa

\section{Pembahasan dan Hasil Penelitian}

Hasil penelitian menunjukkan bahwa terdapat perbedaan hasil belajar siswa dalam pelajaran matematika bila ditinjau dari metode pembeljaran CTL, metode konvensional dan tingkat motivasi

1. Pengaruh penggunaan metode pembelajaran CTL dengan konvensional terhadap hasil belajar matematika.

$\begin{array}{ccr}\text { Dari } & \text { hasil } & \text { penelitian } \\ \text { menunjukkan } & \text { bahwa } & \text { kelompok } \\ \text { penggunaan } & \text { metode } & \text { belajar }\end{array}$
matematika antara metode CTL dan konvensinal diperoleh $F_{\text {hitung }}=39.107$. $F_{\text {tabel }}=2,87$. Dengan demikian hipotesis pertama teruji kebenarannya secara signifikan dan dapat diterima. Sehingga dapat disimpulkan terdapat perbedaan pengaruh yang signifikan penggunaan metode CTL dan konvensional terhadap hasil belajar matematika. Rata-rata hasil belajar matematika yang di ajar dengan menggunkan CTL lebih tinggi 
daripada yang di ajar dengan menggunkan metode konvensional.

Dari hasil analisis deskriptif, diperoleh hasil belajar matematika siswa yang di ajar dengan metode CTL dperoleh hasil: skor terendah 65 , skor tertinggi 100, skor rata-rata sebesar 83,33, median sebesar 82.50, modus sebesar 80, dan simpangan baku sebesar 1,847. Sedangkan pada kelompok siswa yang di ajar dengan menggunkan metode konvensional diperoleh hasil belajar matimatika: skor terendah 55, skor tertinggi 85 , skor rata-rata 70.33, median sebesar 70, modus sebesar 65 dan simpangan baku 1.417. dari data tersebut terihat bahwa selain teruji hasil belajar matematika siswa yang di ajar dengan metode CTL lebih tinggi secara signifikan dari pada yang di ajar dengan metode konvensional

Berdasarkan teory bab II, Penggunaan metode pembelajaran yang tepat dapat membuat siswa lebih kreatif. Hal ini sesuai dengan apa yang diungkapkan Rohman bahwa. Dengan demikian akan tercipta pembelajaran yang lebih menekankan pada pemberdayaan siswa secara aktif. Pembelajaran tidak hanya sekedar menekankan pada penguasaan pengetahuan (logos), tetapi terlebih pada penekanan internalisasi tentang apa yang dipelajari, sehingga terbentuk dan terfungsikan sebagai milik nurani siswa yang berguna dalam kehidupannya (etos).

\section{Pengaruh Rasa Percaya Diri} terhadap Hasil Belajar Mateatika

Dari hasil penelitian menunjukkan bahwa motivai belajar matematika antara rasa percaya diri tinggi dan rendah diperoleh $\mathrm{F}_{\text {hitung }}=$ 9.292. $F_{\text {tabel }}=2,87$. Dengan demikian hipotesis pertama teruji kebenarannya secara signifikan dan dapat diterima. Sehingga dapat disimpulkan terdapat perbedaan pengaruh yang signifikan motivasi tinggi dan rendah terhadap hasil belajar matematika. Rata-rata hasil belajar matematika dengan rasa percaya diri tinggi lebih tinggi daripada yang rasa percaya diri rendah.

Berdasarkan teori, rasa percaya diri merupakan modal dasar untuk pengembangan dalam aktualisasi diri. Hal ini sesuai dengan yang diungkapkan oleh hakim bahwa kepercayaain diri yang positif bisa mencapai berbagai tujuan di dalam hidupnya. Dengan percaya diri akan mampu mengenal dan memahami diri sendiri. Sementara itu, kurang percaya diri dapat menghambat pengembangan potensi diri. Jadi orang yang kurang percaya diri akan menjadi orang yang 
pesimis dalam menghadapi tantangan, takut dan ragu-ragu untuk menyampaikan gagasan, bimbang dalam menentukan pilihan dan sering membanding-bandingkan dirinya dengan orang lain. Dalam proses belajar siswa untuk mencapai tujuan yang diharapkan tentunya pengembangan diri sangatlah dibutuhkan siswa dalam hal melalui pemahaman, sintesis (membuat paduan baru dan utuh), penerimaan, penghayatan, keterampilan bergerak dan bersikap, kecakapan ekspresi verbal dan nonverbal dan sebagainya. Percaya diri sebagai suatu keyakinan seseorang dengan sukses mampu berperilaku seperti yang dibutuhkan untuk mengakibatkan hasil yang diharapkan. Dari definisi ini dapat kita lihat bahwa optimisme adalah faktor atau unsur penting yang harus dimiliki oleh individu yang memiliki kepercayaan diri, sedangkan hal tersebut merupakan pemicu utama dalam pencapaian prestasi atau hasil yang diharapkan.

\section{Pengaruh Interaksi Penggunaan} Metode Belajar dan Rasa Percaya Diri terhadap Hasil Belajar Matematika

$\begin{array}{ccr}\text { Dari } & \text { hasil } & \text { penelitian } \\ \text { menunjukkan } & \text { bahwa } & \text { kelompok } \\ \text { penggunaan } & \text { metode } & \text { belajar }\end{array}$

matematika dan motivasi belajar diperoleh $F_{\text {hitung }}=7.431 . F_{\text {tabel }}=2,87$. Dengan demikian hipotesis ketiga teruji kebenarannya secara signifikan dan dapat diterima. Sehingga dapat disimpulkan terdapat interaksi penggunaan Metode belajar dan rasa percaya diri terhadap hasil belajar matematika

Berdasarkan teory bab II, Rasa percaya diri seperti ini akan tercipta jika guru mengkondisikan situasi pembelajaran yang tidak membosankan. Melalui motivasi belajarnya, guru dan siswa mengkondisikan pembelajaran di kelas menjadi sebuah aktivitas yang menyenangkan. Jadi rasa percaya diri yang efektif dan efisien adalah memotivasikan para siswa untuk belajar giat berdasarkan kebutuhan ilmu mereka masing-masing secara memuaskan, yakni kebutuhan akan pengetahuan yang cukup bagi keperluan siswa, kebahagiaan hidup, kemajuan diri dan sebagainya.

Selain Metode Pengajaran ada faktor lain yang dapat mempengaruhi hasil belajar siswa yaitu kepercayaan diri. Kepercayaan diri merupakan modal dasar untuk pengembangan dalam aktualisasi diri. Dengan percaya diri akan mampu mengenal dan memahami diri sendiri. Sementara itu, 
kurang percaya diri dapat menghambat pengembangan potensi diri. Jadi orang yang kurang percaya diri akan menjadi orang yang pesimis dalam menghadapi tantangan, takut dan ragu-ragu untuk menyampaikan gagasan, bimbang dalam menentukan pilihan dan sering membanding-bandingkan dirinya dengan orang lain.

Dalam proses belajar siswa untuk mencapai tujuan yang diharapkan tentunya pengembangan diri sangatlah dibutuhkan siswa dalam hal melalui pemahaman, sintesis (membuat paduan baru dan utuh), penerimaan, penghayatan, keterampilan bergerak dan bersikap, kecakapan ekspresi verbal dan nonverbal dan sebagainya. Percaya diri sebagai suatu keyakinan seseorang dengan sukses mampu berperilaku seperti yang dibutuhkan untuk mengakibatkan hasil yang diharapkan

\section{Kesimpulan}

Pada bagian kesimpulan ini, penulis uraikan secara singkat hasil penelitian yang diperoleh di lapangan. Setelah diadakan penelitian dan analisis data tentang Pengaruh Metode Belajar dan Rasa Percaya Diri Terhadap Hasil Belajar Matematika Siswa dapat ditarik kesimpulan sebagai berikut :
1. Terdapat pengaruh Metode belajar (A) terhadap Hasil belajar Matematika siswa (Y).

2. Terdapat pengaruh Rasa Percaya Diri (B) terhadap hasil belajar matematika siswa (Y).

3. Terdapat Interaksi antara metode belajar ( A ) dengan rasa percaya diri siswa ( B ). Dengan Pola interaksi

a. Hasil belajar matematika yang di ajar dengan metode CTL dan Rasa Percaya Diri tinggi lebih tinggi dibandingkan dengan hasil belajar yang di ajar dengan Metode CTL dan Rasa Percaya Diri rendah.

b. Hasil belajar matematika yang di ajar dengan Metode Konvensional dan Rasa Percaya Diri tinggi lebih tinggi dibandingkan dengan hasil belajar Metode Konvensional dan Rasa Percaya Diri rendah.

c. Hasil belajar matematika yang di ajar dengan Metode CTL dan Rasa Percaya Diri rendah lebih tinggi dibandingkan dengan hasil belajar metode konvensional dan Rasa Percaya Diri rendah.

\section{Pustaka}

Abin Syamsuddin. 1996. Psikologi Kependidikan Perangkat Sistem Pengajaran Modul._Bandung : PT. Remaja Rosdakarya 
Arifin, Zaenal. 1991. Evaluasi Instruksional. Jakarta : Bina Aksara.

Arikunto, Suharsimi. 2002. Dasar- Dasar Evaluasi Pendidikan. Jakarta: Rineka Cipta.

Borg, Walter R.1983. Educational Research an Introduction. Newyork: Longman.

Crow Lester D and Crow Alice. 1963. Educational Physicology. Newyork: American Book Company.

Darsono, Max, dkk. 2000. Belajar dan Pembelajaran. Semarang:

CV.IKIP Semarang Press.

De Angelis, Barbara. 2000. Self Confident: Percaya Diri Sumber Kesuksesan Dan Kemandirian. Jakarta. Gramedia Pustaka.

Depdiknas. 2002. Pendekatan Kontekstual ( Contextual Teaching and Learning Jakarta: Dirjen, Didasmen, Direktorat Sekolah Lanjutan Pertama . 2002. Manajemen Peningkatan mutu berbasis sekolah (Pembelajaran dan Pengajaran Kontekstual). Jakarta. Direktorat Jendral Pendidikan Dasar dan Menengah Pertama. Jakarta.
Dimyati dan Mudjiono. 2002. Belajar dan Pembelajaran. Jakarta : Rineka Cipta.

Edmonson, Katilerine M. 2000. Concept Mapping for The development of medical curricula. Newyork: Journal research in science teaching, vol. 32 .

Farida, I. (2005). Metode Problem Centered Learning sebagai upaya meningkatkan kemampuan pemecahan masalah matematik siswa. Makalah : tidak diterbitkan. Hamalik, U. 2003. Proses Belajar Mengajar. Jakarta : Bumi Aksara.

Hafriani. 2004. Mengembangkan kemampuan pemecahan masalah matematika mahasiswa melalui Problem Centered Learning. Makalah : tidak diterbitkan.

Hakim, Thursan. 2002. Mengatasi Rasa Tidak Percaya Diri. Jakarta. Puspa Swara.

Hamalik, Oemar. 2003. Proses Belajar Mengajar. Jakarta: Bumi Aksara Meistasari, MT. 1995. Bagaimana Meningkatkan Rasa Percaya Diri. Jakarta. Bina Putra Aksara.

Rochyani, I. A. S. 2004. Meningkatkan Kreativitas Siswa SMA Melalui Pembelajaran Matematika Berbasis Masalah pada Pokok Bahasan Program Linier. 
Makalah. Jakarta : tidak Sudjana, N. 2002. Metode Statistika. diterbitkan Bandung: Tarsito.

Rianto, Yatim. 1996. Metodologi . 2005. Penilaian Hasil Proses Penelitian pendidikan suatu Belajar Matematika. Tinjauan Dasar. Surabaya: SIC Bandung:Remaja Rosdakarya Surabaya. Offset.

Rusefendi, E.T. 1998. Pengajaran Matematika Modern. Bandung: Tarsito Suherman, E. 1996. Model-Model Pembelajaran Matematika. Makalah : tidak diterbitkan

Slameto. 2001.Evaluasi Pendidikan.

Salatiga: Bumi Aksara. 
